\title{
The determinants of financial risk disclosure in annual reports in emerging economies: Evidence from Egypt
}

\author{
Dr / Rasha Mohamed Hamdy El-Haddad \\ Lecturer, Department of Accounting, School of Business,
} Ahram Canadian University

E-mail: rasha.elhaddad@acu.edu.eg

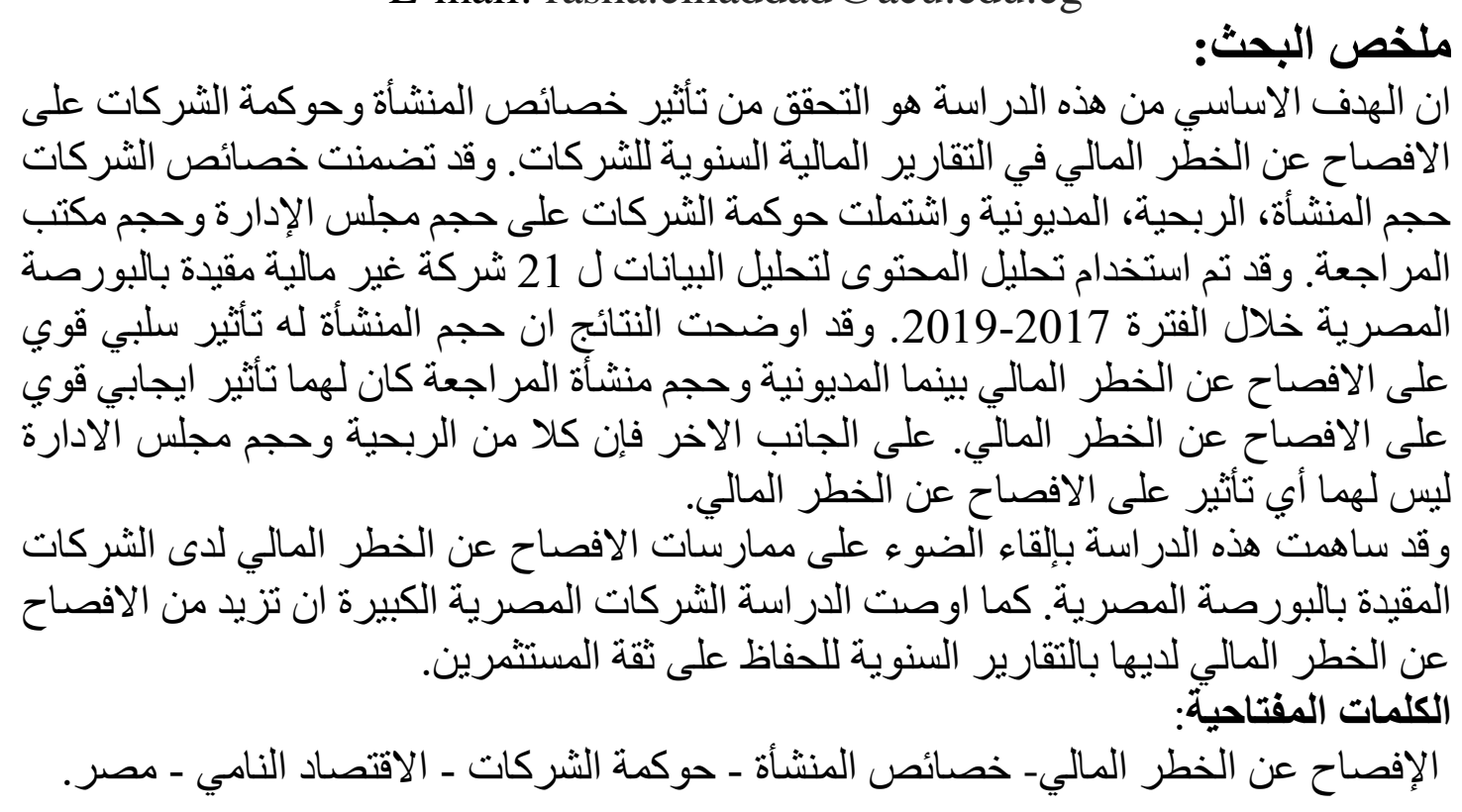

\section{Abstract}

This study aims at investigating the impact of firm and corporate governance determinants on the financial risk disclosure in annual reports. The researcher hypothesized that both the firm characteristics including size, profitability, and leverage and corporate governance characteristics including board size and audit firm size have significant effect on financial risk disclosure. Content analysis was used to analyze the data of 21 nonfinancial companies listed in Egyptian Stock Exchange during the period 2017-2019. The results of the study indicated that firm size has negative effect on the financial risk disclosure, while leverage and audit firm size positively significantly affect the financial risk disclosure. On the other side, both profitability and board size have no significant effect on the financial risk disclosure. However, this paper has contributed to the prior research by shedding the light on financial risk disclosure practices of Egyptian listed non-financial firms. Finally, the research recommends large Egyptian firms to increase their financial risk disclosure in annual reports to maintain the confidence of investors.

Keywords: Financial Risk Disclosure; Firm characteristics; Corporate Governance; Developing Economy; Egypt. 


\section{Introduction}

The development and competition in the business environment increased the importance of information for investment decisions. The current age is information era, but ownership separation and companies' management create a problem of information asymmetries (Elfeky, 2007). Disclosure is the way to provide the required information to users. Higher disclosure is related to a decreased information asymmetry (Kim \& Verrecchia, 1994) and reduced investor uncertainty (Botosan, 1997).

Recent financial scandals around the world increased the significance of Risk Disclosure (RD) (Oliveira et al., 2013). Lack of disclosure will cause a risk of information gap. Annual reports and the firm's risk disclosures will be useful tools to decrease this gap (Elfeky, 2007; Khlif \& Hussainey, 2016).

Several authors gave attention to the need of RD (Schrand \& Elliott, 1998; Elshandidy et. al., 2013; Cabedo \& Tirado, 2014). Also, Kwok (2003) indicates that RD may increase the precision of forecasting profits.

Some studies explored RD using content analysis (e.g., Linsley \& Shrives, 2006; Lombardi et al., 2016; Dicuonzo et al., 2017; Dey et al., 2018; Elshandidy et al., 2018). Firms strive to reveal more information about various risks to satisfy accounting information users' needs (Elzahar \& Hussainey, 2012). However, some studies indicated that companies are providing insufficient information about the risk (Khlif \& Hussainey, 2016).

Prior literature and regulating bodies classified the Corporate Risk Disclosure (CRD) into different types (e.g., Cabedo \& Tirado, 2004; Lindqvist, 2016; Chen, 2019; Maverick, 2019). A study by Cabedo \& Tirado (2014) indicated that the classification of CRD involves two categories, namely, non-financial risks involving business and strategic risks, and Financial Risks (FRs) that include market, liquidity, and credit. Also, FRs were classified by IFRS 7 into four categories: market, credit, liquidity, and price risks (Dicuonzo et al., 2017). It was noted that FR consists of market, liquidity, and credit risks where market risk arises due to some factors, such as interest rate, foreign exchange, and commodity price-sensitive revenues or expenses (Vandemele et al., 2009). Some companies are subject to FRs that arise from financing activities (Taylor et al., 2010). Therefore, the FRs are the main concern of this current study. As a preamble to the recent increase in risk research, prior research concentrated on the determinants of CRD (e.g., Beretta \& Bozzolan, 2004; Lajili \& Zéghal, 2005; Abraham and Cox, 2007; Vandemele et al., 2009; Elshandidy et al., 2013). Rare studies explored the factors that affect the Financial Risk Disclosure (FRD) (e.g., Taylor et al., 2010; Lombardi et al., 
2016; Dicuonzo et al., 2017; Dey et al., 2018) which can be considered as a gap in related research. So, the current study attempts to answer the following question: Whether firm and corporate governance characteristics affected FRD in emerging economies? That question can be answered by investigating the factors that affect FRD in an emerging economy.

The current study aims at investigating the determinants of FRD in annual reports of non-financial listed companies in Egypt. The study tries to fill in the gap concerning the influence of both firm and corporate governance characteristics on FRD in Egypt. This is the first study, to the best of my knowledge, undertaken in Egypt that explores the determinants of FRD. Most mandatory rules are concerned with FRD (Elzahar \& Hussainey, 2012).

The study contributes to risk literature through examining the factors that affect the FRD in an emerging economy. Thus, the findings of this study may be useful for both regulators and stakeholders, especially, in developing countries.

The remainder of this study is presented as follows. Next section reviews prior literature. Third section develops research hypotheses. Fourth section determines the research methodology followed by the section that presents the empirical analysis and last section concludes.

\section{Literature review}

Recently, emerging markets attracted the attention of international companies (Millar et al., 2005). However, the level of disclosed information in these markets is low (Tower et al., 2011). Full disclosure occurs when financial reports facilitate the understanding of accounting practices and decision-making (Nichita, 2019). RD is a report including information about firm's strategies, operations, and other factors that may affect expected results (Beretta \& Bozzolan, 2004). Firms may face different types of risks in their work, such as FRs.

The financial risk, as defined by Maverick (2019), is a type of corporate risks that may jeopardize the business, public sector, and financial markets. This risk is the probability that shareholders or investors will lose capital. Based on insights from various classifications of FRs in recent research (e.g., Dicuonzo et al., 2017; Dey et al., 2018; Netti, 2018), the current study will consider the disclosure of five types of FRs, which are credit, liquidity, price, exchange rate, and interest rate risks. FRD, whether in developed or emerging markets, may be affected by some determinants as firm and corporate governance characteristics.

Many studies explored RD focusing on the association between risk information disclosed and firm attributes (e.g., Marshall \& Weetman, 2002; Konishi \& Ali, 2007; Agyei-Mensah, 2012; Khlif \& Hussainey, 2016; Elshandidy et al., 2018) and other studies focused on the corporate 
governance characteristics, and their effect on CRD level (Samaha and Dahawy, 2011; Hussainey \& Al-Najjar, 2011).

Several studies examined CRD in developed countries including Canada (Lajili \&Zéghal 2005), United Kingdom (Linsley \& Shrives 2006; Elzahar \& Hussainey 2012), Italy (Beretta \& Bozzolan 2004; Netti, 2018), Spain (Cabedo \& Tirado, 2014), Japan (Konishi \& Ali, 2007), and Finland (Lindqvist, 2016). These studies discussed CRD with less emphasis on FRD. Few studies examined FRD in developed economies such as Italy (Lombardi et al., 2016; Dicuonzo et al., 2017), Australia (Taylor et al., 2010) and in emerging countries such as Bangladesh (Dey et al., 2018).

In the Egyptian context, prior research (e.g., Dahawy, 2009; Samaha \& Dahawy 2010, 2011; Samaha et al., 2012; Soliman, 2013; Abdel-Azim \& Abdelmoniem, 2015; Elfeky, 2017; Abd Elghaffar et al., 2019) investigated the determinants of CRD. Although these studies find an association between RD and firm attributes in Egypt, they do not directly address FRD. Based upon such prior studies, the current study tries to fill this gap in research by investigating the association between FRs (i.e., credit, liquidity, price, foreign exchange rate, and interest rate) and the determinants of the disclosure of these risks in Egypt.

Lajili and Zéghal (2005) focused on CRD of a sample including 300 Canadian listed companies. They identified some risk categories as political risk, technological risk, weather risk, and market risk. FRs (i.e., credit, interest rate, and exchange rate risks) are also investigated. Their results showed a much higher FRD level than other RD level.

Taylor et al. (2010) investigated FRD in annual reports of 111 Australian listed firms during the period of 2002-2006. Then, they related FRD to firm-specific attributes incorporating corporate governance. They hypothesized that there is a positive relationship between both the firm's corporate governance structure and overseas listing by the firm and FRD. Their findings indicated that firm's corporate governance has a significant and positive association with FRD, while overseas stock exchange listing of firms is significantly negatively associated with FRD patterns.

Lombardi et al. (2016) explored the quality of information on FRs included in the annual reports of a sample of 50 non-financial listed Italian companies during the period between 2008 and 2013. Their results indicated the degree of FRD, as well as what companies disclose in terms of FR indices in their management reports and in their notes to the financial statements.

Dicuonzo et al. (2017) indicated that the period (2005-2007) shows an increase in financial risk mandatory disclosure requirements, while nonFR disclosure remained voluntary in Italy. They examined how Italian and Albanian firms disclose relevant information about their FR exposure 
using a content analysis of annual reports of a matched sample of 24 firms from Albania and Italy. They analyzed financial reports of Albanian firms and compared them with Italian companies' financial reports. They classified risk information into seven categories (financial risk management; credit; liquidity; price; interest rate; currency; other financial risks). They found that Italian companies disclose more information on FR than Albanian companies.

A study by Dey et al. (2018) examined the relationship between FRD and firm's attributes. They hypothesized a relationship between company size, performance, and leverage and the FRD. Also, they assumed an effect of liquidity, industry type, and audit firm size on FRD. They analyzed data of 48 companies over six years (2010-2015) in Bangladesh. They evidenced a positive association between the company size, performance, and audit firm size and FRD.

\section{Hypotheses development}

\subsection{Firm characteristics}

Several studies investigated the impact of firm characteristics on CRD level (e.g., Watson et al., 2002; Aly et al., 2010; Oliveira et al. 2011; Hussainey \& Al-Najjar, 2011; Elzahar \& Hussainey, 2012). Most of these studies concluded that the extent of RD may be affected by firm characteristics.

Ahmed \& Courtis (1999) presented a meta-analysis of the results of 23 studies on the association between firm attributes and disclosure levels and found that only firm size, exchange listing status, audit firm size, and leverage significantly positively associated with disclosure levels.

Based upon the findings of previous empirical research on disclosure, the firm characteristics including size, profitability, and leverage were selected in the current research to examine their effect on FRD in Egypt.

\subsubsection{Firm Size}

Agency theory proposes that larger firms have higher information asymmetry between both managers and owners and face greater agency costs. So, large firms are expected to provide a higher disclosure level to reduce information asymmetries (Watts \& Zimmerman, 1983) and decrease these agency costs (Marston \& Polei, 2004). Also, large firms may present more RD because they have more resources.

Several studies considered the firm size as an important determinant of RD (Bretta \& Bozzolan, 2004; Lajili \& Zeghal, 2005; Linsley \& Shrives, 2006) and suggested mixed results on the association between the firm size and RD level. Most studies found a positive (Linsley \& Shrives, 2006; Konishi \& Ali, 2007; Vandemele et al., 2009; Netti, 2018; Elshandidy et al., 2018), while other empirical research showed a negative relationship (Lajili \& 
Zeghal, 2005; Kou \& Hussain, 2007; Hill \& Short, 2009), and few studies did not find significant relationship between firm size and RD (Doyle et al., 2007; Hassan, 2009).

In Egypt, findings of most studies showed a positive association between firm size and RD (Dahawy, 2009; Samaha et al., 2012; Soliman, 2013; Abdel-Azim and Abdel-Moniem, 2015; Elfeky, 2017), while Abd Elghaffar et al. (2019) found an insignificant association between the two variables.

Building on recent and related research that evidenced a significant relationship between the size and FRD (e.g., Dey et al., 2018; Lombardi et al., 2016), the first hypothesis is posited:

Hypothesis1: There is a significant effect of firm size on financial risk disclosure.

\subsubsection{Profitability}

It is expected that high profitable firms will disclose more risk information to justify these profits to stakeholders according to a Signaling theory (Khlif \& Hussainey, 2016; Elfeky, 2017). Also, companies with high profits prefer to disclose more information as means of communicating good signs about their performance (Ghazali \& Weetman, 2006). Concerning investigating the association between profitability and RD, Khlif \& Hussainey (2016) found, in their meta-analysis, empirical research suggested mixed results. Several studies (e.g., Mohobbot, 2005; Wang et al., 2008; Miihkinen, 2012; Elshandidy et al., 2013) found a positive association between profitability and RD. On the other side, some researchers found a negative relationship between profitability and RD level (e.g., Lajili \& Zeghal, 2005; Vandemele et al., 2009), while other studies (e.g., Hasan et al., 2008; Reverte, 2009) find an insignificant association between the two variables.

In Egyptian context, prior research suggested mixed results. Some studies (Elfeky, 2017; Soliman, 2013) supported a positive relationship between profitability and RD, while Abd Elghaffar et al. (2019) found an insignificant association between both variables.

Concerning the relationship between profitability and FRD, some studies (e.g., Dey et al., 2018; Lombardi et al., 2016) found this association to be positive. Based on a signaling theory and results of related research, the following hypothesis was formulated:

$\mathrm{H} 2$ : There is a significant effect of profitability on the financial risk disclosure.

\subsubsection{Leverage}

According to agency theory, a firm with high debt may have higher agency costs. The management needs to reveal more information to satisfy the creditors, which in turn, reduces these agency costs (Elzahar \& Hussainey, 
2012). Risk disclosure related to market, credit, and internal control may have an important role in reducing creditors' concerns about the firm solvency and its ability to generate future cash flow (Rajab \& HandleySchachler 2009).

Current empirical evidence presented mixed results, including positive (Taylor et al., 2010; Elshandidy et al., 2013) and negative (Aryani \& Hussainey, 2017) relationship between the firm leverage and RD. Also, some researchers did not find a significant relationship (e.g., Hussainey \& Al-Najjar, 2011; Allini et al., 2016; Netti, 2018; Dey et al., 2018) between the two variables.

In Egypt, Elfeky (2017) found a positive significant correlation between firm leverage and RD, while Abd Elghaffar et al. (2019) found a negative significant correlation.

The firm leverage may affect FRD level (Dey et al., 2018). Based on prior literature, a relationship between leverage and FRD is predictable. Hence, the following hypothesis is postulated:

H3: There is an effect of firm leverage on financial risk disclosure.

\subsection{Corporate Governance Characteristics}

Taylor et al. (2010) suggested that companies with a strong corporate governance structure will have enhanced financial risk management disclosures. The current research uses board size and audit firm size in examining the influence of corporate governance structure on FRD.

\subsubsection{Board Size}

Companies with a large board of directors will reveal additional information in the annual reports (Elfeky, 2017). Prior research found a positive relationship between board size and RD such as Li et al. (2008), while Rao \& Jirra (2017) found a negative relationship. On the other side, some studies found insignificant association between these two variables (e.g., Lakhal, 2005; Elzahar \& Hussainey, 2012).

In the Egyptian context, various studies evidenced a significant positive association between board size and RD (e.g., Ezat \& Elmasry, 2008; Samaha \& Dahawy, 2011; Mokhtar \& Mellett, 2013; Elghaffar et al., 2019), while Elfeky (2017) found an insignificant association. Based on previous results, the next hypothesis is tested:

$\mathrm{H}$ 4: There is a significant impact of board size on the financial risk disclosure.

\subsubsection{Audit Firm Size}

Small audit firms are more sensitive to client demands to avoid the loss of a client, while larger audit firms tend to encourage the clients to disclose more information to maintain the audit firm's reputation (Chalmers \& 
Godfrey, 2004). Thus, the companies, which are audited by Big 4 audit firms, may disclose more information upon the request of the auditor.

Prior research investigated the relationship between the auditor type and RD (e.g., Lopes \& Rodrigues, 2007; Wang et al., 2008; Dey et al., 2018). Some studies evidenced a positive association (Lopes \& Rodrigues, 2007; Oliveira et al., 2011), whereas Dumes \& Knechel (2008) found a negative association, and other studies failed to find a significant association between auditor type and risk disclosure (Wallace et al., 1994; Hossain et al., 1995).

In Egypt, some studies found a significant positive association between the type of audit firm and RD level (Soliman, 2013; Elfeky, 2017; Abd Elghaffar et al., 2019).

A study by Dey et al. (2018) evidenced a significant positive association between auditor type and FRD level. Thus, the following hypothesis is proposed:

H5: There is a significant effect of audit firm size on the financial risk disclosure.

\section{Methodology}

\subsection{Sample and Data}

Financial reports include all the necessary data. The sample of the study consists of 25 Egyptian listed companies over the period 2017-2019. The study selected the largest non-financial companies from the Egyptian Stock Exchange (EGX). The total number of firms in EGX is 30 and after excluding 5 financial institutions, the sample includes only 25 nonfinancial institutions. Also, the researcher excluded 4 companies during data collection because of incomplete data.

The researcher collected required data from annual reports of firms in the sample. The data for the annual report of 2020 was not available at the time of the analyses. The main sources of data used in the analysis were both the Egyptian Stock Exchange and firm Websites. Egyptian Stock Exchange and Mubashir Miser websites were used to select the sample of the Egyptian non-financial firms. Also, annual reports of selected firms were downloaded from each firm website to collect the data related to total assets, profits, debt, board size, and audit firm size. Finally, the current sample size is 21 companies (63 firm-year observations) during the period 2017-2019 (see Appendix A).

\subsection{Analysis Method}

This study used a content analysis to measure and analyze FRD. It investigated the annual reports for Egyptian listed companies including 
sections that present information on risks, specifically focusing on financial risks as follows: credit, liquidity, currency, interest rate, market price risks. These five types of FRs were included within FRD index calculation.

\subsection{Financial Risk Disclosure Index}

FRD index was formulated to measure FRD on five categories of financial risk (as shown in Appendix B) to construct a customized risk disclosure score. A dichotomous procedure was used to calculate the disclosure of a company which assigns a score of 1 if the company discloses a risk category and 0 otherwise (Soliman, 2013). A disclosure index was computed by dividing the actual score given to the company by the maximum score. It is to be noted that the information was manually collected and analyzed. Prior studies used RD index to measure the quality and quantity of RD (Beattie et al., 2004; Botosan, 1997). In this study the index was calculated according to the following formula:

$\mathbf{I}_{\mathbf{f}}=\frac{\mathbf{P}}{\mathbf{T}}$

Where:

$\mathrm{I}_{\mathrm{f}}=$ financial risk disclosure index that refers to an individual firm

$\mathrm{P}=\sum$ Actual Score - points scored by the firm

$\mathrm{T}=\sum$ Maximum Score - total points of maximum risk disclosure

P presents number of points scored by each firm. The maximum score for financial risks is 5 , where 1 point was given for each financial risk category $(0 \leq \mathrm{P} \leq 5)$. Stands for the total figure corresponding to all the financial risk categories and it was calculated by giving 1 for each type of financial risk disclosed $(\mathrm{T}=5)$.

\subsection{Measurement of variables}

The dependent variable of the study is FRD, while firm characteristics and corporate governance are the independent variables. The firm characteristics were measured by the firm size, profitability, and leverage, while both board size and audit firm size were used as proxies to measure the corporate governance.

The list of dependent and independent variables used, and their measurements are presented in Table (1). 
Table 1. List of variables

\begin{tabular}{|c|c|c|c|c|}
\hline Variable & $\begin{array}{l}\text { Type of } \\
\text { Variables }\end{array}$ & Proxies & Code & Measurement \\
\hline $\begin{array}{l}\text { Financial Risk } \\
\text { Disclosure }\end{array}$ & Dependent & $\begin{array}{l}\text { Financial } \\
\text { Risk } \\
\text { Disclosure } \\
\text { Index }\end{array}$ & FRD & $\begin{array}{l}\text { Ratio of actual } \\
\text { score given to } \\
\text { the firm divided } \\
\text { by the maximum } \\
\text { score. }\end{array}$ \\
\hline \multirow[t]{3}{*}{$\begin{array}{l}\text { Firm } \\
\text { Characteristics }\end{array}$} & \multirow[t]{3}{*}{ Independent } & Firm Size & FIRS & $\begin{array}{l}\text { Logarithm of } \\
\text { Total Assets }\end{array}$ \\
\hline & & Profitability & ROA & $\begin{array}{l}\text { Net Income after } \\
\text { tax/Total Assets }\end{array}$ \\
\hline & & Leverage & LEV & $\begin{array}{l}\text { Total } \\
\text { Liabilities/Total } \\
\text { Assets }\end{array}$ \\
\hline \multirow[t]{2}{*}{$\begin{array}{l}\text { Corporate } \\
\text { Governance } \\
\text { Structure }\end{array}$} & \multirow[t]{2}{*}{ Independent } & Board Size & BRDS & $\begin{array}{ll}\text { Number } & \text { of } \\
\text { Board } & \text { of } \\
\text { Directors } & \end{array}$ \\
\hline & & $\begin{array}{l}\text { Audit Firm } \\
\text { Size } \\
\text { (Dummy) }\end{array}$ & $\mathrm{AS}$ & 1 or 0 \\
\hline
\end{tabular}

\subsection{Model Development}

The Model used to test the relationship between the FRD and both firm characteristics and corporate governance is presented below:

$\mathrm{FRD}=\mathrm{b} 0+\mathrm{b} 1 \mathrm{FIRS}+\mathrm{b} 2 \mathrm{ROA}+\mathrm{b} 3 \mathrm{LEV}+\mathrm{b} 4 \mathrm{BRDS}+\mathrm{b} 5 \mathrm{AS}+\varepsilon$

Where:

FRD: financial risk disclosure; FIRS: firm size; ROA: profitability; LEV: Leverage; BRDS: board size; AS: auditor size $=1$ if the auditor is one of the Big 4, 0 otherwise; $\varepsilon$ : Error Term

\section{Results and Discussion}

\subsection{Descriptive Statistics:}

\section{Frequency Tables}

Table (2), (3) below presents the frequency tables of FRD and auditor firm size:

Table (2) Frequency Table of Financial Risk Disclosure 
FRD Index Frequency Percent

\begin{tabular}{lll}
\hline $\mathbf{2 0}$ & 3 & 4.8 \\
\hline $\mathbf{4 0}$ & 3 & 4.8 \\
\hline $\mathbf{6 0}$ & 4 & 6.3 \\
\hline $\mathbf{8 0}$ & 32 & 50.8 \\
\hline $\mathbf{1 0 0}$ & 21 & 33.3 \\
\hline $\begin{array}{l}\text { Tota } \\
\mathbf{1}\end{array}$ & $\mathbf{1 0 0 . 0}$ \\
\hline
\end{tabular}

Table (2) above shows that the frequency of FRD of 80 value represents the largest number of observations with 32 observations, equivalent to $51 \%$ of the total observations, while both the 20 and 40 values represent only three observations each, equivalent to $5 \%$ each.

Table (3) Frequency Table of Auditor Firm Size

\begin{tabular}{ccl}
$\begin{array}{l}\text { Audit } \\
\text { size }\end{array}$ & \multicolumn{2}{c|}{$\mathbf{f i r m F r e q u e n c}$} \\
& \multicolumn{1}{c}{ Percent } \\
\hline Small 23 & 36.5 \\
\hline Large 40 & 63.5 \\
\hline Total 63 & $\mathbf{1 0 0 . 0}$
\end{tabular}

Table (3) shows that the frequency of the large audit firm is 40 , equivalent to $63.5 \%$ of the total observations, while the small Audit Firm is 23, equivalent to $36.5 \%$ of the total observations. It means that most companies in the sample were audited by Big 4 audit firms.

Table (4) Descriptive Statistics

\begin{tabular}{|c|c|c|c|c|c|c|}
\hline \multicolumn{3}{|c|}{ FRD } & \multirow{2}{*}{$\begin{array}{l}\text { FIRS } \\
63\end{array}$} & \multirow{2}{*}{$\begin{array}{l}\text { ROA } \\
63\end{array}$} & \multirow{2}{*}{$\begin{array}{l}\text { LEV } \\
63\end{array}$} & \multirow{2}{*}{$\begin{array}{l}\text { BRDS } \\
63\end{array}$} \\
\hline$\overline{\mathbf{N}}$ & Valid & 63 & & & & \\
\hline & Missing & 0 & 0 & 0 & 0 & 0 \\
\hline \multicolumn{2}{|c|}{ Mean } & 80.63 & 9.9048 & 34.45870 & .61837 & 9.05 \\
\hline \multicolumn{3}{|c|}{ Std. Deviation 20.310} & .59812 & 15.559552 & .189268 & 3.045 \\
\hline \multicolumn{2}{|c|}{ Variance } & 412.494 & .358 & 30.909 & .036 & 9.272 \\
\hline
\end{tabular}




\begin{tabular}{lllllll|}
\hline Range & 80 & 2.6365 & 27.500 & .750 & 13 \\
\hline Minimum & 20 & 8.3800 & -4.500 & .180 & 5 \\
\hline Maximum & 100 & 11.0165 & 23.000 & .930 & 18 \\
\hline
\end{tabular}

The results of the descriptive statistics of the dependent (FRD) and independent variables (firm size, profitability, leverage, and board size) were shown in table (4):

The first row labeled $\mathrm{N}$, represents the number of observations, which equals 63 for all variables, and there are no missing values for any of the variables. The mean of FRD is 80.63 namely most of the total number of financial risks were considered in the study, with a range of 20 to 100, with a standard deviation equals 20 . The table shows the average firm size (FIRS) is 9.9, with a range of 8.38 to 11.02 , with a low standard deviation equals to 0.6. Additionally, the above table shows that the average of "Profitability" (ROA) is 4.46 , with a range of -4.5 to 23 , with a standard deviation equals 5.56. The mean of "Leverage" (LEV) was 0.62, with a range of 0.18 to 0.93 , with a standard deviation equals 0.19 . At last, the average of "Board Size" (BRDS) was 9.05 with a range of 5 to 18 , with a standard deviation equals to 3.05 .

\subsection{Correlations Matrix:}

Table (5) below provides the correlation coefficient of the dependent and independent variables. It sets out the presence of a significant association between the following independent variables: firm size and auditor firm size, profitability and leverage, leverage and board size, board size and profitability, auditor firm size and board size. Also, the results show that there is a significant negative correlation between the dependent variable (financial risk disclosure) and the independent variable (firm size) which is -0.32 . Besides, there is a significant positive correlation between the dependent variable FRD and the independent variable (auditor firm size) which is 0.28 . These findings support the argument that companies audited by Big 4 audit firms have higher FRD than firms audited by non-Big 4 . 
Table (5) Correlation Matrix

FRD FIRS ROA LEV BRDSAS

\begin{tabular}{|c|c|c|c|c|c|c|c|}
\hline $\begin{array}{l}\text { Financial } \\
\text { Disclosure }\end{array}$ & $\begin{array}{r}\text { RiskCorrelation } \\
\text { Coefficient }\end{array}$ & 1.000 & $\begin{array}{l}-.326- \\
* * *\end{array}$ & .002 & .130 & .229 & $.275^{*}$ \\
\hline & Sig. (2-tailed) & & .009 & .986 & .311 & .071 & .029 \\
\hline Firm Size & $\begin{array}{l}\text { Correlation } \\
\text { Coefficient }\end{array}$ & $-.326-^{* *}$ & 1.000 & $-.132-$ & .243 & $-.003-$ & $.289^{*}$ \\
\hline & Sig. (2-tailed) & .009 & & .301 & .055 & .982 & .022 \\
\hline Profitability & $\begin{array}{l}\text { Correlation } \\
\text { Coefficient }\end{array}$ & .002 & $-.132-$ & 1.000 & $-.610-$ & $.289^{*}$ & - \\
\hline & Sig. (2-tailed) & .986 & .301 & & .000 & .022 & .462 \\
\hline Leverage & $\begin{array}{l}\text { Correlation } \\
\text { Coefficient }\end{array}$ & .130 & .243 & -.610- & 1.000 & $\begin{array}{l}-.270- \\
* \\
*\end{array}$ & .164 \\
\hline & Sig. (2-tailed) & .311 & .055 & .000 & . & .032 & .199 \\
\hline Board Size & $\begin{array}{l}\text { Correlation } \\
\text { Coefficient }\end{array}$ & .229 & $-.003-$ & $.289^{*}$ & $-.270-$ & 1.000 & $.316^{*}$ \\
\hline & Sig. (2-tailed) & .071 & .982 & .022 & .032 & & .012 \\
\hline $\begin{array}{l}\text { Auditor } \\
\text { Size }\end{array}$ & $\begin{array}{r}\text { FirmCorrelation } \\
\text { Coefficient }\end{array}$ & $.275^{*}$ & $.289^{*}$ & $-.094-$ & .164 & $.316^{*}$ & 1.000 \\
\hline & Sig. (2-tailed) & .029 & .022 & .462 & .199 & .012 & \\
\hline
\end{tabular}

\subsection{Coefficient of Determination:}

The adjusted coefficient of determination (Adjusted R Square) of the model in table (6) indicates that $23.2 \%$ of the variation in the dependent variable is explained by variations in the independent variables, which confirms the efficiency of the model. 
Table (6) Coefficient of Determination

\begin{tabular}{l|ll}
$\mathbf{R}$ & \multicolumn{2}{c}{$\begin{array}{c}\text { Adjusted } \mathbf{R} \\
\text { R SquareSquare }\end{array}$} \\
\hline $.542^{\mathrm{a}}$ & .294 & $\mathbf{. 2 3 2}$ \\
\hline
\end{tabular}

\subsection{Analysis of Variance (ANOVA):}

As presented in table (7) the multiple regression model reported an $\mathrm{F}$ value of $4.75(\mathrm{p}<0.05)$ for FRD level, which statistically supports the significance of the model.

\section{Table (7) ANOVA ${ }^{\mathrm{a}}$}

\begin{tabular}{|lllll|l} 
Model & $\begin{array}{l}\text { Sum } \\
\text { Squares }\end{array}$ & of & $\begin{array}{l}\text { Mean } \\
\text { Square }\end{array}$ & F & Sig. \\
\hline $\begin{array}{l}\text { Regressio } \\
\mathbf{n}\end{array}$ & 7521.563 & 5 & 1504.313 & 4.750 & $\mathbf{. 0 0 1}^{\mathbf{b}}$ \\
\hline $\begin{array}{l}\text { Residual } \\
\text { Total }\end{array}$ & 18053.040 & 57 & 316.720 & & \\
\hline
\end{tabular}

a. Dependent Variable: Financial Risk Disclosure

b. Predictors: (Constant), Auditor Firm Size, Profitability, Firm Size, Board Size, Leverage

\subsection{Regression Model:}

Table (8) provides the results of the Ordinary Least Square (OLS) regression for the model using the Enter method. The regression model indicates that there is a negative significant effect of firm size on FRD. Also, there is a positive significant effect of Leverage and auditor firm size on FRD.

The hypotheses of the study predicted a significant effect of firm size, profitability, leverage, board size, and audit firm size on FRD. The findings identify the significant effect of firm size, leverage, and audit firm size on FRD. These results support the first, third, and last hypotheses, while both hypothesis 2 and hypothesis 4 were not supported. The firm size has been found to be negatively and significantly correlated with FRD. This output is consistent with the results of some previous studies (e.g., Lajili \& Zeghal, 2005; Kou \& Hussain, 2007; Hill \& Short, 2009; Dominguez \& Gamez, 2014). It can be explained by the notion that small companies are willing to increase the confidence of investors to enhance their reputation 
and increase the market share by increasing the FRD in the annual reports. On the other side, it has been found that leverage positively affects FRD. This finding is consistent with agency theory, where this effect may be due to companies with high leverage need to disclose more information to satisfy the creditors, and in line with studies by Dumes \& Knechel (2008), Elshandidy et al. (2013), and Elfeky (2017). Also, it has been found that there is a significant positive effect of audit firm size on FRD. This finding is like results of Dey et al. (2018) and suggests that the Big 4 audit firms strive to maintain their reputation by ensuring that their clients disclose more information. However, there is no statistically significant effect of profitability and board size on RD. This outcome is consistent with the results that were reached by Lakhal, 2005; Elzahar \& Hussainey, 2012; Elfekey, 2017).

Table (8) Regression Model

UnstandardizedStandardized

Coefficients Coefficients

Collinearity Statistics

Std.

Model B $\quad$ Error Beta $\quad t \quad$ Sig. Tolerance VIF

\begin{tabular}{|c|c|c|c|c|c|c|}
\hline (Constant & )197.240 & 41.276 & & 4.779 & .000 & \\
\hline FIRS & -15.743 & -4.173 & $-.464-$ & - & .000 .820 & 1.220 \\
\hline & & & & $3.772-$ & & \\
\hline ROA & 1.033 & .528 & .283 & 1.958 & .055 .594 & 1.685 \\
\hline LEV & 35.542 & 15.469 & .331 & 2.298 & .025 .596 & 1.678 \\
\hline BRDS & .368 & .894 & .055 & .412 & .682 .690 & 1.450 \\
\hline AS & 14.824 & 5.331 & .354 & 2.781 & .007 .763 & 1.310 \\
\hline
\end{tabular}

Multicollinearity in explanatory variables has been diagnosed through Variable Inflation Factors (VIF). The (VIF) more than 10 should be considered an indication of harmful multicollinearity. Alternatively, if the average VIF is substantially greater than one, then the regression may be biased. Table (8) shows that the average of VIF is (1.00) and that ensures the collinearity is not a problem for this model. These results suggest that multicollinearity between the independent variables is unlikely to pose a serious problem in the interpretation of the results of the multivariate analysis. 
As a result, second and fourth hypotheses are rejected, while first, third, and last hypotheses which propose a significant effect of firm size, leverage, and auditor firm size on FRD are accepted since study findings support these hypotheses.

\section{Conclusion and Future Research}

The study contributes to the prior research in several ways. This is the first attempt to investigate FRD as a type of CRD in non-financial companies listed in the Egyptian stock Exchange. It also contributes to the literature on whether the firm and corporate governance characteristics that have been found to be significant in developed countries can be applied in emerging economies like Egypt. The results indicated that firm size has a significant negative effect on FRD, while both leverage and auditor size positively and significantly affect the FRD. On the other side, both profitability and board size have insignificant effect on FRD.

The findings contribute to the accounting literature by providing an understanding of FRD practices in Egypt. Also, the main contribution is clarifying the importance of FRD in annual reports of Egyptian firms.

This study recommends the management of Egyptian companies to enhance the quality of FRD in annual reports. This will increase the confidence of their investors and satisfy their creditors. Also, large companies with high profit and large board size may need to give more attention to the disclosure of financial risk in annual reports. In addition, regulatory bodies in Egypt should guide Egyptian companies to disclose more information about financial risks.

However, there are some limitations in this study. First, the study is confined to country in emerging economies that may not indicate the situation in other countries. Also, the sample was limited to non-financial firms that are listed in the Egyptian Stock Exchange (EGX30) for 3 years, that can be considered small and insufficient to generalize the results. Thus, the results need to be interpreted carefully due to these limitations.

Future research can reexamine the determinants of FRD in other developing countries. Also, sample can be expanded to include non-listed and financial companies. In addition, further research is required to consider the effect of other firm characteristics and corporate governance factors (i.e., liquidity, cross listing, role duality, audit committee size) on FRD. Additional research can be undertaken to analyze the economic effects of FRD. 
Appendix A. List of sample firms

\begin{tabular}{|ll|}
\hline Firm Name & \\
Label & \\
1-Alexandria Mineral Oils & AMOC \\
2-Eastern Tobacco & EAST \\
3-El Sewedy Electric & SWDY \\
4-sodic & OCDI \\
5-Juhayna Food & JUFO \\
6-Heliopolis Housing & HELH \\
7-Sidi Kerir & SKPC \\
8-orascom construction & ORC \\
9-GB Auto & AUTO \\
10-TMG & TMGH \\
11-Egyptian tourism resort & EGTS \\
12-Kima & KIMA \\
13-Emaar misr & EMFD \\
14-Ezz steel & ES \\
15-Cleopatra Hospital & CLH \\
16-Cairo for investment & CFIRE \\
and real estate & PH \\
17-Palm Hills & EKH \\
18-EKH & DI \\
19-Dice & PORT \\
20-porto group holding & MNHD \\
21-Medinet Nasr housing & MN \\
\hline
\end{tabular}

Appendix B. Financial Risk Categories

\begin{tabular}{|l|}
\hline Financial Risks \\
\hline 1-Credit \\
\hline 2-Liquidity \\
\hline 3-Currency \\
\hline 4-Interest rate \\
\hline 5-Market price \\
\hline
\end{tabular}




\section{References:}

1. Abd Elghaffar, E. S., Abotalib, A. and Khalil, M. 2019. Determining factors that affect risk disclosure level in Egyptian banks. Banks and Bank Systems, 14(1): 159-171.

2. Abdel-Azim, M. H. and Abdelmoniem, Z. 2015. Risk management and disclosure and their impact on firm value: The case of Egypt. International Journal of Business, Accounting, and Finance, 9 (1): $1-14$.

3. Abraham, S., and Cox, P. 2007. Analyzing the determinants of narrative risk information in UK FTSE 100 annual reports. The British Accounting Review, 39(3): 227-248.

4. Agyei-Mensah, B. K. 2012. Association between firm-specific characteristics and levels of disclosure of financial information of rural banks in the Ashanti region of Ghana. Journal of Applied Finance \& Banking, 2(1): 69-92.

5. Ahmed, K., and Courtis, J. 1999. Associations between corporate characteristics and disclosure levels in annual reports: A metaanalysis. British Accounting Review, 31(1): 35-61.

6. Allini, A., Manes Rossi, F., and Hussainey, K. 2016. The board's role in risk disclosure: An exploratory study of Italian listed stateowned enterprises. Public Money \& Management, 36(2): 113-120.

7. Aly, D., Simon, J. and Hussainy, K. 2010. Determinants of corporate internet reporting: evidence from Egypt. Managerial Auditing Journal, 25(2): 182-202.

8. Aryni, D. N., and Hussainey, K. (2017). The Determinants of Risk Disclosure in the Indonesian Non listed Banks. International Journal Trade and Global Markets, 10(1), 58-66.

9. Beattie, V., McInnes, B., \& Fearnley, S. (2004). A methodology for analyzing and evaluating narratives in annual reports: a comprehensive descriptive profile and metrics for disclosure quality attributes. Accounting Forum, 28: 205-236.

10.Beretta, S., and Bozzolan, S. 2004. A framework for the analysis of firm risk communication. International Journal of Accounting, 39(3): 265-288.

11.Botosan, C. A. 1997. Disclosure level and the cost of equity capital. The Accounting Review, 72(3): 323-349.

12.Cabedo, D. and Tirado, J. 2004. The disclosure of risk in financial statements. Accounting Forum, 28(2): 181-200.

13.Cabedo, D. and Tirado, J. 2014. Risk disclosure and cost of equity: The Spanish case. Accounting and Management, 59 (4): 105-135. 
14.Chalmers, K., and Godfrey, Jayne M. 2004. Reputation costs: The impetus for voluntary derivative financial instrument reporting. Accounting Organizations and Society, 29: 95-125.

15.Chen, J. 2019. Financial risk. Corporate Finance and Accounting. Available: www.Investopedia.com

16.Dahawy, K. 2009. Company characteristics and disclosure level: The case of Egypt. International Research Journal of Finance and Economics, 34: 194-208.

17.Deumes, R. and Knechel, W. 2008. Economic incentives for voluntary reporting on internal risk management and control systems. Auditing: A Journal of Practice \& Theory, 27(1): 35-66.

18.Dey, R., Hossain, S., and Rezaee, Z. 2018. Financial Risk Disclosure and Financial Attributes among Publicly Traded Manufacturing Companies: Evidence from Bangladesh. Journal of Risk and Financial Management, 50(11): 1-16.

19.Dicuonzo, G., Fusco, A. and, Dell'Atti, V. 2017. Financial Risk Disclosure: Evidence from Albanian and Italian Companies. EBEEC Conference Proceedings, The Economies of Balkan and Eastern Europe Countries in the Changed World, KnE Social Sciences, 182-196.

20.Domínguez, L. R. and Gámez, L. C. 2014. Corporate reporting on risks: Evidence from Spanish companies. Spanish Accounting Review, 17(2): 116-129.

21.Doyle, J., W. Ge, and S. McVay. 2007. Accruals Quality and Internal Control over Financial Reporting. The Accounting Review, 82: 1141-1170.

22.Elfeky, M. I. 2017. The extent of voluntary disclosure and its determinants in emerging markets: Evidence from Egypt. The Journal of Finance and Data Science, 3, 45-59.

23.Elshandidy, T., Fraser, I., \& Hussainey, K. 2013. Aggregated, voluntary, and mandatory risk reporting incentives: Evidence from FTSE all-share. International Review of Financial Analysis, 30: 320-333.

24.Elshandidy, T., Neri, L., and Guo, Y. 2018. Determinants and impacts of risk disclosure quality: Evidence from China. Journal of Applied Accounting Research: 1-28.

25.Elzahar, H., and Hussainey, K. 2012. Determinants of narrative risk disclosures in UK interim reports. Journal of Risk Finance, 13(2): 133-147.

26.Ezat, A., and El-Masry, A. 2008. The impact of corporate governance on the timeliness of corporate internet reporting by Egyptian listed companies. Managerial Finance, 34(12): 848-867. 
27.Ghazali, N. and Weetman, P. 2006. Perpetuating traditional influences: Voluntary disclosure in Malaysia following the economic crisis. Journal International Accounting, Auditing \& Taxation, 4(2): 226-248.

28.Khlif, H., and Hussainey, K. 2016. The association between risk disclosure and firm characteristics: a meta-analysis. Journal of Risk Research, 19(2): 181-211.

29.Hasan, T., Karim, W., and Quayes, S. 2008. Regulatory change and the quality of compliance to mandatory disclosure requirements: Evidence from Bangladesh. Research in Accounting Regulation, 20: 193-203.

30.Hassan, M. 2009. UAE corporations-specific characteristics and level of risk disclosure. Managerial Auditing Journal, 24 (7): 668687.

31.Hill, P., \& Short, H. (2009). Risk disclosures on the second-tier markets of the London Stock Exchange. Accounting \& Finance, 49(4), 753-780.

32.Hossain, M., Perera, B., and Rahman, R. 1995. Voluntary disclosure in the annual reports of New Zealand companies", Journal of International Financial Management and Accounting, 6: 69-87.

33.Hussainey, K., and Al-Najjar, B. 2011. Future-oriented narrative reporting: determinants and use. Journal of Applied Accounting Research, 12(2): 123-138.

34.Kim, O., and R. Verrecchia 1994. Market liquidity and volume around earnings announcements. Journal of Accounting and Economics, 17 (1\&2): 41-67.

35.Konishi, N., and Ali, M. 2007. Risk reporting of Japanese companies and its association with corporate characteristics. International Journal of Accounting, Auditing and Performance Evaluation, 4(3), 263-285.

36.Kou, W. and Hussain, S. 2007. Predictive gains to segmental disclosure matrices, geographic information, and industry sector comparability. The British Accounting Review, 39(3): 183-195.

37.Kwok, B. 2003. The effect of mandated market risk disclosures on the quality of information contained in analysts' earnings forecasts. Working Paper, Singapore Management University.

38.Lajili, K., and Zéghal, D. 2005. A content analysis of risk management disclosures in Canada annual reports. Canada Journal of Administrative Science, 22: 125-42.

39.Lakhal, F. 2005. Voluntary earnings disclosures and corporate governance: evidence from France. Accounting and Finance Review, 4(3): 64-85 
40.Li, J., Pike, R .and Haniffa, R. 2008. Intellectual capital disclosure and corporate governance structure in UK firms. Accounting and Business Research, 38(2): 137-159.

41.Lindqvist, A. 2016. What Drives Risk Disclosure Quality? The Impact of the Financial Crisis. Master's thesis, Hanken School of Economics, Helsinki.

42.Linsley, P. M., and Shrives, P. J. 2006. Risk reporting: a study of risk disclosures in the annual report of UK companies. The British Accounting Review, 38(4): 387-404.

43.Lombardi, R., Coluccia, D., Russo, G., and Solimene, S. 2016. Exploring financial risks from corporate disclosure: Evidence from Italian listed companies. Journal of the Knowledge Economy, 7: 309-327.

44.Lopes, P. T., and Rodrigues, L. L. 2007. Accounting for financial instruments: An analysis of the determinants of disclosure in the Portuguese Stock Exchange. International Journal of Accounting, 42(1): 25-56.

45.Marshall, A., Weetman, P. 2002. Information asymmetry in disclosure of foreign exchange risk management: can regulation be effective? Journal of Business and Economics, 54: 31-53.

46. Marston, C., and Polei, A. 2004. Corporate reporting on the internet by German companies. International Journal of Accounting Information System, 285-311.

47.Maverick, J., 2019. financial risk vs Business risk: An Overview, Corporate Finance and Accounting. available: www.Investopedia.com

48.Miihkinen, A. 2012. What Drives Quality of Firm Risk Disclosure? The Impact of a National Disclosure Standard and Reporting Incentives under IFRS. The International Journal of Accounting, 47 (4): 437-468.

49.Millar, C., Eldomiaty, T., Choi, C., and Hilton, B. 2005. Corporate governance and institutional transparency in emerging markets. Journal of Business Ethics, 59 (1-2): 163-74.

50.Mohobbot, A. 2005. Corporate risk reporting practices in annual reports of Japanese Companies. Japanese Journal of Accounting, 16(1): 113-133.

51.Mokhtar, E. S., and Mellett, H. 2013. Competition, Corporate Governance, Ownership Structure, and Risk Reporting. Managerial Auditing Journal, 28(9): 838-865.

52.Netti, A. 2018. Firm determinants of risk disclosure: Evidence from Italian listed companies, Corporate Ownership \& Control, 16(1): 168-177. 
53.Nichita, M., 2019. Intangible Assets - Insights from a Literature Review. Accounting and Management Information Systems, 18 (2): 224-261

54.Oliveira, J., Rodrigues, L. L., \& Craig, R. 2011. Risk-related Disclosures by Non-Finance Companies: Portuguese Practices and Disclosure Characteristics. Managerial Auditing Journal, 26(9): 817-839.

55.Oliveira, J., Rodrigues, L. L., and Craig, R. 2013. Public visibility and risk-related disclosures in Portuguese credit institutions. Journal of Risk, 15(4): 57- 90.

56.Rajab, B., and Handley-Schachler, M. 2009. Corporate risk disclosure by UK firms: Trends and determinants. World Review of Entrepreneurship Management and Sustainable Development, 5(3): 224-243.

57.Reverte, C. 2009. Determinants of corporate social responsibility disclosure ratings by Spanish listed firms. Journal of Business Ethics 88: 351-66.

58.Roa, K. S., and Jirra, T. D. 2017. Analysis of risk disclosure practices of commercial banks in Ethiopia. Indian Journal of Research, 6(2): 260-262.

59.Samaha, K., and Dahawy, K. 2010. Factors influencing corporate disclosure transparency in the active share trading firms: an explanatory study. Research in Accounting in Emerging Economies,10: 87-118.

60.Samaha, K., and Dahawy, K. 2011. An empirical analysis of corporate governance structures and voluntary corporate disclosure in volatile capital markets: the Egyptian experience. International Journal of Accounting, Auditing, and Performance Evaluation 7(1): 61-93.

61.Samaha, K., Dahawy, K., Hussainey, K., and Stapleton, P. 2012. The extent of corporate governance disclosure and its determinants in a developing market: The case of Egypt. Advances in Accounting, 28(1): 168-178.

62.Schrand, C. M., \& Elliott, J. A. (1998). Risk and financial reporting: A summary of the discussion at the 1997 AAA/FASB Conference. Accounting Horizons, 12(3): 271-282.

63. Soliman, M. 2013. Firm characteristics and the extent of voluntary disclosure: the case of Egypt. Research Journal of Finance and Accounting, 4(17): 71-81.

64.Taylor, G., Tower, G., and Neilson, J. 2010. Corporate communication of financial risk. Accounting and Finance, 50(2): 417-446. 
65.Tower, G., Vu, K., and Scully, G. 2011. Corporate communication for Vietnamese listed firms. Asian Review of Accounting, 19(2): 125-146.

66. Vandemele, S., Vergauwen, P., and Michiels, A. 2009. Management risk reporting practices and their determinants: a study of Belgian listed firms. Available at: https://www.researchgate.net

67.Wallace, R., Naser, K., and Mora, A. 1994. The relationship between comprehensiveness of corporate annual reports and firm characteristics in Spain. Accounting \& Business Research, 25(97): 41-53.

68.Wang K., Sewon, O., and Claiborne, C. 2008. Determinants and consequences of voluntary disclosure in an emerging market: evidence from China. Journal International Accounting, Auditing \& Taxation, 17(4): 14-30.

69. Watson, A., Shrives, P., and Marston, C. 2002. Voluntary disclosure of accounting ratios in the UK. British Accounting Review, 34: 289-313.

70.Watts, R., and Zimmerman, J. 1983. Agency Problems, Auditing, and the Theory of the Firm: Some Evidence. Journal of Law and Economics, 2: 613-633. 